\title{
South Korean efforts to transition to a hydrogen economy
}

\author{
Troy Stangarone ${ }^{1}$ (1)
}

Received: 31 March 2020 / Accepted: 27 August 2020 / Published online: 11 September 2020

(c) Springer-Verlag GmbH Germany, part of Springer Nature 2020

\begin{abstract}
As the world increasingly looks to renewable energy sources to deal with climate change, South Korea is aiming to become a leader in the development of hydrogen as an alternative energy source. In developing an ecosystem for a hydrogen economy, South Korea is focused on increasing the production and use of hydrogen vehicles, establishing an ecosystem for the production and distribution of hydrogen and related technologies, and expanding the production of fuel cells. The government's vision has the backing of key industrial firms, most importantly the Hyundai Motors Group which plans on investing 7.6 trillion won ( $\$ 6.7$ billion) under its "FCEV Vision 2030" and is part of the HyNet consortium to build 100 new hydrogen refueling stations in South Korea by 2022. If South Korea's vision is successful, it expects hydrogen to account for $5 \%$ of its projected power consumption in 2040, to see its economy grow by 43 trillion won, 420,000 new jobs created, and significant reductions in both fine dust and greenhouse gas emission.
\end{abstract}

\section{Graphic abstract}

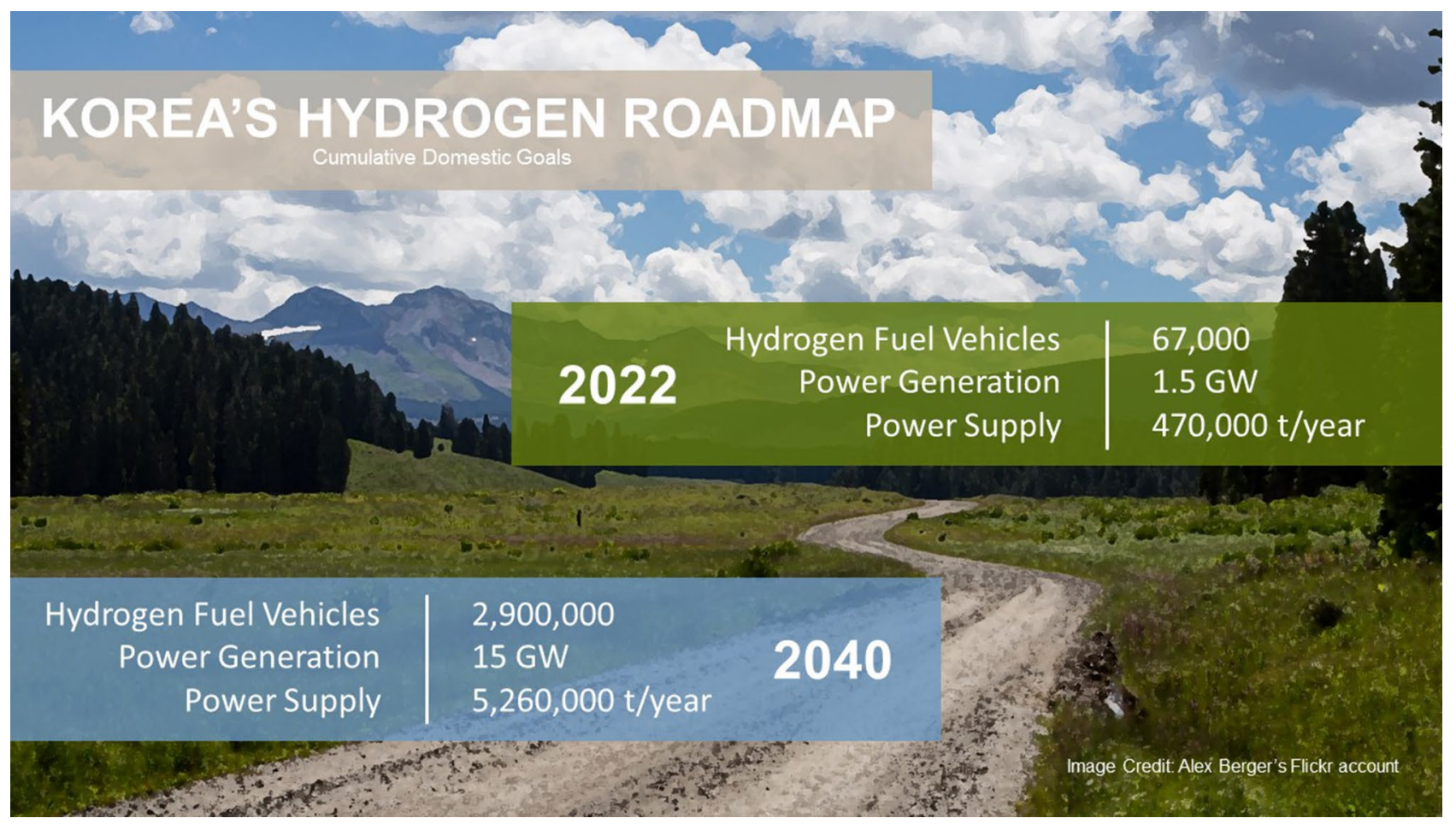

Keywords Hydrogen · Hydrogen economy $\cdot$ FCEVs $\cdot$ Fuel cells $\cdot$ Roadmap $\cdot$ South Korea

Troy Stangarone

ts@keia.org

Extended author information available on the last page of the article 
As the world increasingly looks to renewable energy sources to deal with climate change, South Korea is aiming to become a leader in the development of the hydrogen economy. The vision laid out by South Korean President Moon Jae-in calls for South Korea to focus on increasing the production and use of hydrogen vehicles, establishing an ecosystem for the production and distribution of hydrogen and related technologies, and expanding the production of fuel cells.

While the Hydrogen Economy Roadmap developed by the Moon administration covers different components of developing a hydrogen-based economy, much of the plan will rest on South Korea's ability to expand the acceptance of fuel cell electric vehicles (FCEVs) first in South Korea's domestic market and in time in markets around the world.

However, if South Korea is successful in developing hydrogen as more than a niche energy source domestically, its success could serve as a demonstration of the technology's viability and offer insights into the best means of transitioning to a hydrogen-based economy.

\section{Why South Korea is pursuing a hydrogen-based economy}

As South Korea and the international community work to decarbonize energy, hydrogen is increasingly viewed as a promising alternative that can address South Korean concerns related to the environment, energy security, and economic growth.

While South Korea does have offshore wind potential (International Energy Agency 2019), its onshore wind and solar potential are more limited (ESMAP 2020). While green hydrogen can be produced with renewable energy, the ability to utilize gray hydrogen produced from gasoline, biomass, methane, and other sources gives it more flexibility even with varying degrees of pollution depending on the fossil fuel used to produce the hydrogen (Hydrogen Energy Center).

Hydrogen is also becoming more economically viable as an energy source. The Hydrogen Council estimates that hydrogen will become increasingly competitive over the coming decade as prices fall by $50 \%$ and it expects that hydrogen will become the renewable energy of choice in areas such as industrial heating and long and heavy-duty trucking (Hydrogen Council 2020).

The flexibility of hydrogen fuel cells provides other advantages. McKinsey \& Company estimates that hydrogen can play a role in transforming the world's energy infrastructure in a series of areas: long-term energy storage, the distribution of energy, energy resilience, cleaner feedstock for chemicals, and decarbonizing the transport, industrial, and building sectors (Heid 2017).
In the transport sector, hydrogen also has certain advantages over electric and gasoline vehicles. As an energy source, hydrogen has a higher density of energy than gasoline. While electric vehicles still trail gasoline-powered vehicles in driving range, hydrogen vehicles can be built with a comparable driving range to gasoline vehicles (Malloy 2019). Advances could further reduce constraints on hydrogen vehicles with recent research on the development of a manganese hydride molecular sieve that would reduce both the cost and weight of hydrogen systems (Morris et al. 2019). Hydrogen vehicles can also be refueled 15 times faster than the charge time for fast charging stations, the stations take up less space than electric charging stations, and they are also less intensive on natural resources (Heid 2019).

South Korea's decision to invest in developing a hydrogen-based economy also aligns with domestic needs. In announcing South Korea's hydrogen economy roadmap, President Moon Jae-in laid out three reasons for pursing a hydrogen-based economy - economic growth, energy security, and the environment (Cheong Wa Dae 2019a, b).

\section{Economic growth}

With the world's lowest total fertility rate, South Korea's population is aging more quickly than other developed countries, including Japan. One consequence of the decline in fertility and an aging population is the slowing of South Korea's economic growth potential (Stangarone 2020b).

To address concerns about a slowing economy and increasing competition from rising developing countries such as China, the South Korean government is investing in promising emerging technologies to foster a series of new engines for economic growth that will help keep the economy competitive and spur job creation. In addition to industries related to the utilization of hydrogen as a fuel source, South Korea has identified 5G, artificial intelligence (Song 2019), system semiconductors, biotechnology, and autonomous vehicles as other promising industries to foster (Cheong Wa Dae 2019a, b).

If South Korea is able to achieve the objectives laid out in its Hydrogen Economy Roadmap, it would make South Korea a leader in a new renewable energy field and a growing industrial segment. The South Korean government estimates that this would add 43 trillion won to the economy and create 420,000 new jobs by 2040 .

\section{Energy security}

With only trace amounts of fossil fuel deposits, South Korea is dependent on imports for $98 \%$ of its fossil fuel needs. South Korea's power generation largely consists of fossil fuels and nuclear power, with petroleum accounting for $44 \%$ of energy consumption. In the case of petroleum, 
South Korea has historically been reliant on imports from the Middle East with the region accounting for $81 \%$ of South Korea's petroleum imports in 2017 (U.S. Energy Information Agency 2018).

Nuclear power accounts for $22 \%$ of South Korea's power generation and $11 \%$ of consumption, but with no domestic supplies of uranium South Korea is also dependent imports for nuclear fuel (World Nuclear Association 2019).

The South Korean government estimates that hydrogen could account for $5 \%$ of its expected energy consumption in 2040 , if the objectives in its roadmap are achieved.

\section{Environmental factors}

South Korea is one of the world's largest emitters of greenhouse gases on a per capita basis. In 2018, South Korea's emissions of CO2 reached 624 MT and $12.1 \mathrm{~T}$ per capita according to the International Energy Agency. In South Korea's Paris Climate Accord submission, it pledged to reduce emissions by $37 \%$ from its 2030 business as usual baseline which was estimated to be 850.6 metric tons. To meet these goals, it will need to increase its use of renewable energy.

Air pollution has also become a growing public concern in South Korea. Hazardous air pollution, often associated with developing countries, has become more common. In 2017, South Korea saw a significant increase in the number of days that required ultra-fine dust (PM2.5) warnings (Harris and Kang 2017). The most recent summary of the Joint Research Project for Long-range Transboundary Air Pollutants in Northeast Asia commissioned by South Korea, China, and Japan found on average in 2017 that $51.2 \%$ of PM2.5 in major South Korea cities was domestic in origin, while $32.1 \%$ came from China (National Institute of Environmental Research 2019).

The growth in air pollution has public health consequences for South Korea. According to the University of Chicago's Air Quality Life Index, the average South Korean can expect their life expectancy to decrease by 1.4 years with a more significant decline for those living in Seoul (Energy Policy Institute at the University of Chicago 2019). Additionally, the Organization for Economic Cooperation and Development (OECD) projects that South Korea will be among the countries with the most significant increase in number of premature deaths among OECD members by 2060 (Organization for Economic Cooperation and Development 2016).

The issue of air pollution is also gaining political salience. It was a prominent political issue in the 2017 presidential elections (Fifield 2017), and the continuing challenges South Korea faces from air pollution remain one of the most significant reasons voters say that they disapprove of the policies of President Moon. Those in their 20s and 30s are most likely to list fine dust as a reason to disapprove of President Moon's policies, but more broadly $81 \%$ of South Koreans are concerned about the levels of PM2.5 in South Korea (Gallup Korea 2019).

Hydrogen is part of the South Korean government's plan for addressing greenhouse gas emissions and ultra-fine dust. The South Korean government estimates that if its targets for hydrogen vehicles are met, it could reduce fine dust by 2373 metric tons a year and greenhouse gas emissions by 27.28 million metric tons in 2040. In terms of fine dust, the closure over time of coal-based plants would have a significant impact if South Korea took stronger measures to reduce its usage of coal. In late 2019, South Korea temporarily cut generation from coal plants to $80 \%$ of capacity and saw fine dust decline by $46 \%$ (Yonhap News Agency 2019).

\section{South Korea's hydrogen economy roadmap}

In 2019, South Korea published a roadmap for promoting a hydrogen-based economy that focuses on the transportation sector, decarbonizing industry and buildings, and managing the production and distribution of hydrogen. The roadmap and subsequent legislation passed by the National Assembly are designed to provide objectives, outlines for industry support, and a legal foundation for South Korea's efforts to pursue the development of hydrogen as a fuel source.

At the center of South Korea's strategy is an effort to "prime the pump to create a bigger market" for hydrogen and provide the support needed at this early stage for the private sector to grow the market for hydrogen in the long-term and reach the economies of scale to reduce prices (Cheong Wa Dae 2019a, b). In addition to providing support to the private sector in the form of subsidies for hydrogen projects, R\&D, and regulatory reform, South Korea is working to develop and demonstrate the viability of hydrogen fuel cells. As part of its demonstration efforts, South Korea plans to establish three hydrogen demonstration cities by 2022 . These cities would use hydrogen for transportation, electricity, heating, and cooling, while serving as an initial step in transitioning $30 \%$ of South Korea's cities to hydrogen by 2040 (Edmond 2019).

\section{Transportation and construction industry}

The roadmap places significant emphasis on the transportation sector. Despite efforts to reduce greenhouse gas emissions, vehicles with combustion engines still dominate the global market. Global sales of electric vehicles, the leading alternative to the combustion engine, only amounted to 2.1 million units in 2018 and just $2.2 \%$ of all vehicles sold (Hertzke 2019). Hydrogen vehicles account for a much small part of the market with sales of only about 7500 vehicles in 
2019 (Kane 2020a). However, the South Korean government estimates that if just $10 \%$ of the global automobile market shifts to hydrogen, the new market for hydrogen vehicles would be worth around $\$ 125$ billion.

Despite the current low sales volume for hydrogen vehicles, South Korea hopes to expand domestic production of hydrogen FCEVs to 35,000 units by 2022 and 65,000 hydrogen FCEVs on South Korean roads. By 2025, it has targeted production of 100,000 units with 40,000 units for export. It also estimates that at volumes of 100,000 units the price of hydrogen vehicles would be competitive with internal combustion engine vehicles (Government of Korea 2019). By 2030, hydrogen and electric vehicles are expected to make up a third of all new cars sold domestically (Kang 2020b).

To encourage the sale of hydrogen vehicles domestically, South Korea's roadmap calls for subsidizing the purchase price of vehicles and investing in R\&D. Under South Korea's subsidy scheme, the level of subsidy would fall as the price of vehicles declines with increased production. In 2020, South Korea has adjusted its subsidy scheme for ecofriendly vehicles and will provide upwards of 42.5 million won $(\$ 34,715)$ for the purchase of a hydrogen vehicle (Yonhap News Agency 2020d), while under its current budget, it is set to spend 43.1 billion won in R\&D on hydrogen-related technologies in 2020 (Yonhap News Agency 2020e).

In addition to passenger vehicles, South Korea's roadmap also calls for the expansion of hydrogen into other areas of transport. For personal travel, the roadmap calls for the introduction of 80,000 hydrogen taxis and 40,000 hydrogen buses by 2040. It also calls for the introduction of 30,000 hydrogen trucks over the same period for the transportation of freight.

The roadmap also includes steps for research into utilizing hydrogen to power ships, trains, drones, and construction equipment, but these areas are more focused on $R \& D$ with the goal of being able to commercialize the technology before 2030 .

\section{Refueling stations}

Similar to the adoption of electric vehicles, the lack of refueling stations remains an obstacle to the adoption of hydrogen-powered vehicles more widely. South Korea's roadmap calls for expanding the number of refueling stations from the current 34 stations to 310 in 2022 and 1200 by 2040 (Kang 2020a). South Korea plans on providing subsidies and reducing regulations to encourage the construction of new refueling stations to facilitate this expansion.

Under the government's roadmap, different types of subsidies would be available for different types of installations. In urban areas, the Ministry of Environment would provide subsidies of $50 \%$ of the installation cost per station up to 1.5 billion won, while the Ministry of Land, Infrastructure, and Transport would provide 750 million won per station on highways. South Korea also plans on loosening regulations on the location and approval process for the installation of hydrogen refueling stations, as well as using new provisions for the establishment of a regulatory sandbox to ease installation in the short term.

\section{Power generation and supply}

South Korea currently generates 307.6 MW from fuel cells, but has targeted expanding that production to $15 \mathrm{GW}$ by 2040 . The expectation in the roadmap is that $8 \mathrm{GW}$ would be for domestic use, while $7 \mathrm{GW}$ would be dedicated to exports. To foster the production of power through fuel cells, the government would implement an LNG price exclusively for fuel cells and maintain renewable energy certificates (RECs) over a period of time to provide investors with a degree of certainty. It would also provide additional value to RECs for green hydrogen projects and is considering a long-term, fixed price system for power generated from fuel cells.

The roadmap has also set the goal of providing households and other buildings $2.1 \mathrm{GW}$ of power from fuel cells by 2040 . This market would be grown through a mixture of incentives such as a special electricity tariff and mandatory steps such as the replacement of cooling systems at public institutions with fuel cell systems.

If the demand for hydrogen grows in line with South Korea's hydrogen roadmap, demand for hydrogen would increase from 130,000 tons in 2019 to 5.36 million tons a year in 2040. Currently, South Korea's hydrogen needs are supplied from byproducts in the petrochemical process. As demand grows in the early stages, South Korea would produce hydrogen using LNG. However, in the longer term it is also considering options for producing green hydrogen. These include using surplus renewable energy and hydrogen produced in conjunction with the development of new largescale renewable energy projects. The roadmap also expects South Korea to begin importing green hydrogen by 2030 . To ease the domestic shipment of imported hydrogen, South Korea is considering installing pipelines at the point of import. These and other potential pipeline initiatives would add to South Korea's current 200-km hydrogen pipeline.

The Korea Gas Corporation (KOGAS) has also developed its own hydrogen plan. The state owned KOGAS plans to invest 4.7 trillion won ( $\$ 4.06$ billion) by 2030 on R\&D the construction of 25 hydrogen production facilities and $700 \mathrm{~km}$ of new pipeline. With increased domestic production and imports of hydrogen beginning in 2030, KOGAS hopes to bring the domestic price of a kilogram of hydrogen down to 3000 won from its current price of $6500-7500$ won by 2040 (Kim and Suh 2019). 


\section{Legal framework}

At the beginning of 2020, South Korea's National Assembly passed the Hydrogen Economy Promotion and Hydrogen Safety Management Law. The legislation, the first of its kind internationally, provided the legal framework for the government's efforts, including the subsidies that South Korea is providing to the industry. It also established the "Hydrogen Economy Committee," chaired by the Prime Minister, which will serve as a control tower to oversee issues related to industry promotion, distribution, and safety (Ministry of Trade, Industry, and Energy 2020).

While the legislation provided a legal framework for the government's efforts to develop hydrogen as a fuel source, legislation related to enforcement of ordinances and the enforcement of rules is still needed.

\section{Other governmental policies related to hydrogen}

In response to the economic consequences of COVID-19, South Korea has developed a policy response not to just manage the economic consequences of COVID-19 but also to prepare the economy for the post-COVID period known as the Korean New Deal (Stangarone 2020a).

The Korean New Deal is divided into two planks, the Digital New Deal and the Green New Deal. Under the Green New Deal, the Moon administration aims to accelerate South Korea's transition from a carbon-dependent economy to a low-carbon economy and is committed to spending 42.7 trillion won on green projects by 2025. As part of the Green New Deal, South Korea has set a new target to have 200,000 hydrogen vehicles on the road by 2025 (Government of the Republic of Korea 2020).

The Green New Deal will also expand subsidies for hydrogen vehicles. Hydrogen-powered trucks will be eligible for subsidies from 2021, and subsidies from fuel rechargers for commercial vehicles will become available in 2022 . All hydrogen vehicles will be eligible for state subsidies by 2025 (Kim and Kim 2020).

South Korea has also taken other steps to encourage the use of hydrogen. Under its renewable portfolio standards (RPS), South Korea currently generates $7.6 \%$ of its power from renewables. The RPS requires producers with a capacity over $500 \mathrm{MW}$ to generate an increasing amount of power from renewable sources, or to purchase RECs, reaching $10 \%$ in 2022. The RECs are issued based on the type of renewable power generation with extra weight given to certain technologies based on different environmental and technological considerations. While hydrogen fuel cells have one of the higher weights in the system at 2.0, that trails renewable energy technologies linked to energy storage systems (Korea Energy Agency).

The Third Energy Master Plan, which lays out South Korea's long-term energy policy goals and potential implementation steps, also supports the transition to a hydrogenbased economy. It has set a target of generating 30-35\% of South Korea's power through renewables by 2040 . This is up from a prior target of $20 \%$ in 2030 . It also reinforces the move toward eco-friendly vehicles and the prominence of hydrogen in South Korea's plans to transition to renewable energy (Ministry of Industry, Trade, and Energy 2019).

There are also efforts to promote the usage of hydrogen on the local level. The city of Ulsan, where Hyundai Motors has a strong presence, has set a goal of becoming a leading center for the hydrogen economy by tapping into the abundant hydrogen byproduct produced by its chemical industry. By 2030, it is aiming to have $15 \%$ of passenger vehicles and $40 \%$ of city buses run on hydrogen fuel cells. These vehicles would be supported by 60 refueling stations (Cho 2018).

\section{Private sector initiatives}

The Hyundai Motors Group and its affiliates are the most prominent chaebol working to develop hydrogen as a fuel source. In 2013, Hyundai launched the first mass produced FCEV, the Tucson iX35, and is working to develop the technology as a major part of its strategy.

In 2018, Hyundai announced its "FCEV Vision 2030." Under the 2030 vision, Hyundai Motor Group and its suppliers plan to invest 7.6 trillion won ( $\$ 6.7$ billion) in the expansion of facilities and R\&D with the goal of producing 700,000 fuel cell systems annually by 2030 . FCEVs would account for 500,000 of the fuel cells, while the remainder would be for rolling stocks, drones, vessels, and forklifts. In addition to the expanded production of fuel cell-enabled equipment, these investments are expected to create 51,000 jobs (Hyundai Motor Group 2018).

After trailing Toyota in recent years, Hyundai is now the world's largest seller of hydrogen vehicles. With its Nexo SUV currently available in markets such as South Korea, the USA, and the European Union, Hyundai sold 4987 Nexo FCEVs globally, including 4194 of units in South Korea (Kane 2020b). As part of its 2030 plan, it hopes to expand sales to 40,000 FCEVs in 2022, 130,000 in 2025, and 500,000 by 2030 .

At annual sales of 100,000 units, Hyundai estimates that FCEVs will be price competitive with electric vehicles and that strengthened environmental regulations will make fuel cell, electric, and internal combustion engine vehicles equal in total cost.

At a meeting of the Hydrogen Council in 2020, Council Co-chairman Chung Euisun, Executive Vice Chairman of 
the Hyundai Motor Group, suggested that there are three necessities for realizing the adoption of hydrogen as a fuel source more broadly by society-improving safety, reducing costs through the development of related technologies, and increasing the public awareness of hydrogen's merits as an alternative energy source (Yonhap News Agency 2020a, b, c, d, e, f).

But to help popularize the technology, Hyundai is looking to sell hydrogen fuel systems to its competitors and not remain dependent on the sale of its own vehicles (White and Song 2019).

There is the potential for economic synergies between the production of passenger and commercial vehicles, but Hyundai's plans for commercial vehicles are less developed. In 2019, it formed a joint venture, Hyundai Hydrogen Mobility, with H2 Energy in Switzerland to provide 1600 heavy duty trucks for leasing by 2025 . While the venture is currently focused on Switzerland, the expectation in time is to expand to other parts of Europe (Hyundai Motor Group 2019). Hyundai has also announced that it will begin producing commercial vehicles at its plants in China for the local market by 2023 (Yonhap News Agency 2020a, b, c, d, e, f).

In 2020, Hyundai signed a Memorandum of Understanding with the U.S. Department of Energy to collaborate in an assessment of the viability of hydrogen vehicle technology (U.S. Department of Energy 2020). Similar to its efforts in South Korea, for Hyundai to be successful in the USA, it will need the US government or state governments to support the industry through the construction of refueling stations.

Hyundai is not alone in investing in hydrogen fuel cell technology. Doosan recently spun out its fuel cell division into a separate company to advance the division's growth and is set to complete construction on South Korea's first liquid hydrogen plant in 2021 (FuelCellWorks 2019). Doosan's Mobility Division has also developed a hydrogen fuel cell drone designed to provide deliveries in areas with poor infrastructure (Song et al. 2020).

Hanwha Energy has completed the world's first by-product hydrogen power plant, which opened in July 2020 in the Daesan Industrial Complex. The plant utilizes fuel cells produced by Doosan (Lee 2020).

South Korea's dominate steel producer, Posco, also produces both fuel cells and components for fuel cells.

The South Korean government also helped to form a special purpose corporation, HyNet, composed of 13 companies to invest 135 billion won ( $\$ 118.7$ million) to construct 100 refueling stations by 2022 . The consortium would continue to run the stations through 2028 (Lim and Lee 2019).

However, there is still ground that will need to be made up with the infrastructure for electric vehicles. In 2019, there were estimated 65,000 charging stations in South
Korea (Statista 2020) and Tesla alone has built 450 slowcharging stations and 32 super-charging stations (Yonhap News Agency 2020a, b, c, d, e, f).

\section{Additional steps South Korea can take}

South Korea has put forward a comprehensive plan to create the initial infrastructure, $R \& D$, and investment needed to seed the development of a hydrogen economy, building on a foundation of hydrogen fuel cell vehicles and test projects such as the development of hydrogen cities. However, there are additional steeps it should consider.

To further encourage the adoption of hydrogen as a fuel source, South Korea could either increase the weighting for hydrogen fuel cells or include a mandatory requirement similar to the RPS' obligations for solar power. It could also consider a phase out of the sale of new combustion engine vehicles similar to France and the UK to encourage the development of vehicles that run on alternative energy sources.

South Korea's ultimate success will most likely come down to policy consistency. Nurturing hydrogen as a viable power source for the South Korean economy will require long-term support from the Korean government and industry. The current roadmap runs through 2040. However, the nature of South Korea's single-term presidency means that policies are vulnerable to being minimized or reversed by even administrations of similar political ideology.

For the moment, there seems to be cross-party support for developing hydrogen as a fuel source. But South Korea has seen prior shifts in policy emphasis. The Roh Moo-hyun administration began supporting research into hydrogen in the late 1990s, but his successor shifted the emphasis to nuclear power-an energy source that the current administration hopes to phase out. If South Korea is to be successful in creating the ecosystem necessary to develop a hydrogen economy, there will need to be policy consistency in the years ahead.

Funding No funding was used to produce this article.

Availability of data and material All data and materials used in this article are publically available.

\section{Compliance with ethical standards}

Conflict of interest The Korea Economic Institute of America has a contractual relationship for its funding with the Korea Institute of International Economic Policy, a South Korean government-funded think tank. 


\section{References}

Cheong Wa Dae (2019a) Opening remarks by President Moon Jaein at 2019 national fiscal strategy meeting. Cheong Wa Dae. https://english1.president.go.kr/Briefingspeeches/Speeches/595. Accessed 17 Dec 2019

Cheong Wa Dae (2019b) Remarks by President Moon Jae-in at presentation for hydrogen economy roadmap and Ulsan's future energy strategy. Cheong Wa Dae. https://english1.president.go.kr/Brief ingSpeeches/Speeches/110. Accessed 17 Dec 2019

Cho C (2018) Ulsan strives to become global hydrogen leader. The Korea Herald. http://www.koreaherald.com/view.php?ud=20181 022000747. Accessed 12 Jan 2020

Edmond C (2019) South Korea is building 3 hydrogen-powered cities for 2022. World Economic Forum. https://www.weforum.org/ agenda/2019/11/south-korea-green-energy-hydrogen-future-cityfossil-fuel-renewables/. Accessed 10 Feb 2020

Energy Policy Institute at the University of Chicago (2019) South Korea analysis: air pollution cuts lives short by more than a year. Energy Policy Institute at the University of Chicago, Chicago. Accessed 22 Mar 2020

ESMAP (2020) Global photovoltaic power potential by country. World Bank, Washington. http://documents1.worldbank.org/curated/ en/466331592817725242/pdf/Global-Photovoltaic-Power-Poten tial-by-Country.pdf. Accessed 30 July 2020

Fifield A (2017) Smog becomes a political issue in South Korean election. Washington Post. https://www.washingtonpost.com/world/ asia_pacific/smog-becomes-a-political-issue-in-south-korea n-election/2017/04/27/afd55dba-1a2d-11e7-8598-9a99da559f 9e_story.html. Accessed 10 Mar 2020

FuelCellWorks (2019) Doosan spins out fuel cell business and announces plans to construct Korea's 1st liquid hydrogen plant. FuelCellWorks. https://fuelcellsworks.com/news/doosan-spins -out-fuel-cell-business-and-announces-plans-to-construct-korea s-1st-liquid-hydrogen-plant/. Accessed 10 Feb 2020

Gallup Korea (2019) 데일리 오피니언 제344호(2019년 3월 1주) - 북 핵, 정당별 호감도, 총선 투표 의향 정당 [Daily Opinion No. 344 (Week 1, March 2019)-North Korea's nuclear program, goodwill by party, intention to vote for general election]. Gallup Korea. https://www.gallup.co.kr/gallupdb/reportContent.asp?seqNo $=993$. Accessed 18 Mar 2020

Government of Korea (2019) Hydrogen economy road map. Government of Korea. Accessed 3 Feb 2020

Government of the Republic of Korea (2020) The Korean new deal: national strategy for a great transformation. Government of the Republic of Korea. Accessed 28 Mar 2020

Harris B, Kang B (2017) South Korea joins ranks of world's most polluted countries. Financial Times, London. Accessed 14 Mar 2020

Heid BM (2017) Hydrogen: the next wave for electric vehicles? McKinsey \& Company. https://www.mckinsey.com/industries/autom otive-and-assembly/our-insights/hydrogen-the-next-wave-for-elect ric-vehicles. Accessed 18 Mar 2020

Heid BM (2019) Hydrogen cars or battery electric vehicles-why not both? The trends transforming mobility's future. https://www. mckinsey.com/industries/automotive-and-assembly/our-insights/ the-trends-transforming-mobilitys-future. Accessed 18 Mar 2020

Hertzke PN (2019) Expanding electric-vehicle adoption despite early growing pains. McKinsey \& Company. https://www.mckinsey. com/industries/automotive-and-assembly/our-insights/expandingelectric-vehicle-adoption-despite-early-growing-pains. Accessed 18 Mar 2020

Hydrogen Council (2020) Path to hydrogen competitiveness: a cost perspective. Hydrogen Council. https://hydrogencouncil.com/ wp-content/uploads/2020/01/Path-to-Hydrogen-Competitiveness _Full-Study-1.pdf. Accessed 10 Mar 2020
Hydrogen Energy Center (n.d.) The benefits of hydrogen will move us to a sustainable energy economy. Hydrogen Energy Center. https ://www.hydrogenenergycenter.org/benefits-of-the-hydrogen-econo my. Accessed 10 Mar 2020

Hyundai Motor Group (2018) Hyundai Motor Group reveals 'FCEV Vision 2030'. Hyundai. https://www.hyundai.news/eu/brand/ hyundai-motor-group-reveals-fcev-vision-2030/. Accessed 10 Mar 2020

Hyundai Motor Group (2019) Hyundai Motor and H2 energy sign joint venture contract to spearhead hydrogen mobility in Europe. Hyundai.com. https://www.hyundai.com/worldwide/en/company/ news/news-room/news/Hyundai\%20Motor\%20and $\% 20 \mathrm{H} 2 \% 20$ Energy\%20Sign\%20Joint\%20Venture\%20Contract $\% 20$ to\%20spe arhead\%20Hydrogen\%20Mobility\%20in\%20Europe-0000016205. Accessed 10 Mar 2020

International Energy Agency (2019) Offshore wind outlook 2019: world energy outlook special report. International Energy Agency. https://www.iea.org/reports/offshore-wind-outlook-2019. Accessed 8 Feb 2020

Kane M (2020a) Hydrogen fuel cell car sales in 2019 improved to 7,500 globally. INSIDEEVs. https://insideevs.com/news/397240/ hydrogen-fuel-cell-sales-2019-7500-globally/. Accessed 15 Feb 2020

Kane M (2020b) In 2019 Hyundai sold 80,000 plug-in cars and 5,000 FCVs. INSIDEEVs. https://insideevs.com/news/395333/2019hyundai-sales-80000-plugin-cars/. Accessed 15 Feb 2020

Kang Y (2020a) Korea's hydrogen economy drive going smoothly. Yonhap News Agency. https://en.yna.co.kr/view/AEN2020011 3001300320. Accessed 18 Feb 2020

Kang Y (2020b) S. Korea to invest 385 bln won in R\&D for ecofriendly auto parts. Yonhap News Agency. https://en.yna.co.kr/ view/AEN20200206002800320?section=search. Accessed 18 Feb 2020

Kim J-H, Suh Y-J (2019) Kogas will invest \$4B in hydrogen infrastructure. JoongAng Ilbo. http://koreajoongangdaily.joins.com/news/ article/article. aspx?aid=3062435. Accessed 12 Mar 2020

Kim Y, Kim H (2020) Korea to extend subsidies for electric cars to 2025 to support green New Deal. Pulse. https://pulsenews.co.kr/ view.php?year $=2020 \&$ no $=733375$. Accessed 14 Mar 2020

Korea Energy Agency (n.d.) Renewable portfolio standards. Korea Energy Agency. https://www.energy.or.kr/renew_eng/new/stand ards.aspx. Accessed 20 Mar 2020

Lee H-J (2020) World's first byproduct hydrogen power plant opened. JoongAng Ilbo. https://koreajoongangdaily.joins.com/2020/07/28/ business/industry/world-first-byproduct-hydrogen-plant-Daesa n-Green-Energy/20200728192100399.html\#: :text=Korea\%20for mally $\% 20$ opened $\% 20$ the $\% 20$ world's, electricity $\% 20$ to $\% 20$ sup ply\%20160\%2C000\%20households. Accessed 12 Aug 2020

Lim S, Lee E (2019) S. Korea launches hydrogen charging station building SPC joined by Hyundai. Pulse. https://pulsenews.co.kr/ view.php?sc $=30800021 \&$ year $=2019 \&$ no $=144249$. Accessed 6 Mar 2020

Malloy P (2019) Run on less with hydrogen fuel cells. Rocky Mountain Institute. https://rmi.org/run-on-less-with-hydrogen-fuel-cells/

Ministry of Industry, Trade, and Energy (2019) Third energy master plan: a new energy paradigm for the future. Ministry of Industry, Trade, and Energy. http://www.motie.go.kr/www/main.do. Accessed 19 Mar 2020

Ministry of Trade, Industry, and Energy (2020) World's first hydrogen law enacted (Hydrogen Economy Promotion and Hydrogen Safety Management Act) [세계 최초, 수소법 제정(수소경제 육성 및 수 소 안 전관리법)]. Ministry of Trade, Industry, and Energy. http://www.korea.kr/news/pressReleaseView.do?newsId=15637 0411\&call_from=naver_news. Accessed 12 Mar 2020

Morris L, Hales JJ, Trudeau ML et al (2019) A manganese hydride molecular sieve for practical hydrogen storage under ambient 
conditions. Energy Environ Sci 12:1580-1591. Accessed 16 Aug 2020

National Institute of Environmental Research (2019) Summary report of the 4th stage (2013-2017) LTP project. National Institute of Environmental Research. https://www.nier.go.kr/NIER/cop/bbs/ selectNoLoginBoardArticle.do

Organization for Economic Cooperation and Development (2016) The economic consequences of outdoor air pollution. OECD Publishing, Paris. Accessed 21 Feb 2020

Song J (2019) Seoul unveils biggest stimulus plan since global financial crisis. Financial Times. https://www.ft.com/content/5e813 d5a-ca0a-11e9-a1f4-3669401ba76f. Accessed 19 Feb 2020

Song G, Choi K, Lee H (2020) Doosan to venture into African drone mkt with hydrogen drone solutions. Pulse. https://pulsenews.co.kr/ view.php?year=2020\&no=123407. Accessed 19 Mar 2020

Stangarone T (2020a) Building South Korea's economy after the great pandemic recession. East Asia Forum. https://www.eastasiaforum. org/2020/07/29/building-south-koreas-economy-after-the-great -pandemic-recession/. Accessed 14 Aug 2020

Stangarone T (2020b) South Korea's population may have already peaked. The Diplomat. https://thediplomat.com/2020/02/south -koreas-population-may-have-already-peaked/. Accessed 14 Aug 2020

Statista (2020) Estimated number of electric vehicle charging stations in South Korea from 2016 to 2020

U.S. Department of Energy (2020) U.S. Department of Energy Joins Industry to Collaborate on Transportation Technology Validation and Assessment. Energy.gov. https://www.energy.gov/artic les/us-department-energy-joins-industry-collaborate-transporta tion-technology-validation-and. Accessed 18 Feb 2020

U.S. Energy Information Agency (2018) South Korea. U.S. Energy Information Agency. https://www.eia.gov/international/analysis/ country/KOR. Accessed 3 Mar 2020

White E, Song J (2019) Hyundai urges rivals to buy its fuel cell tech to boost sector. Financial Times. https://www.ft.com/content/a9362 bca-832a-11e9-9935-ad75bb96c849. Accessed 5 Mar 2020
World Nuclear Association (2019) Nuclear power in South Korea. World Nuclear Association. https://www.world-nuclear.org/infor mation-library/country-profiles/countries-o-s/south-korea.aspx. Accessed 18 Mar 2020

Yonhap News Agency (2019) Fine dust emissions sharply down amid coal plant cap. Yonhap News Agency. https://en.yna.co.kr/view/ AEN20191211004200320. Accessed 12 Feb 2020

Yonhap News Agency (2020a) Assembly passes eased data regulation, introduces prosecution reform bill. Yonhap News Agency. https ://en.yna.co.kr/view/AEN20200109007352315?section=search. Accessed 12 Feb 2020

Yonhap News Agency (2020b) Hyundai Motor chief proposes 3 requirements to promote hydrogen society. Yonhap News Agency. https://en.yna.co.kr/view/AEN20200121004500320?secti on=search. Accessed 3 Mar 2020

Yonhap News Agency (2020c) Hyundai Motor to produce hydrogen commercial cars in China. Yonhap News Agency. https://en.yna. co.kr/view/AEN20200121008300320?section=search. Accessed 8 Mar 2020

Yonhap News Agency (2020d) S. Korea changes subsidy scheme for eco-friendly autos. Yonhap News Agency, Seoul. Accessed 8 Mar 2020

Yonhap News Agency (2020e) S. Korea to jack up spending on energy R\&D in 2020. Yonhap News Agency. https://en.yna.co.kr/view/ AEN20200120002800320?section=search. Accessed 14 Mar 2020

Yonhap News Agency (2020f) Tesla basks in stellar performance in S. Korea on EV demand. Yonhap News Agency, Seoul. Accessed 17 Aug 2020

Publisher's Note Springer Nature remains neutral with regard to jurisdictional claims in published maps and institutional affiliations.

\section{Affiliations}

\section{Troy Stangarone ${ }^{1}$ (10}

1 Korea Economic Institute of America, Washington, DC, USA 